\title{
Synergic Interaction between Ascorbic Acid and Antibiotics against Pseudomonas aeruginosa
}

\author{
Luciana Cursino $^{1,2}$, Edmar Chartone-Souza $^{1}$ and Andréa Maria Amaral Nascimento ${ }^{1 *}$ \\ ${ }^{1}$ Departamento de Biologia Geral; Universidade Federal de Minas Gerais; Avenida Antônio Carlos, 6627; 31270-901; \\ Belo Horizonte - MG - Brazil. ${ }^{2}$ Departamento de Genética ESALQ/USP; Av. Pádua Dias, 11; 1340-097; Piracicaba - \\ SP - Brazil
}

\begin{abstract}
Studies were carried out on in vitro combination of ascorbic acid (AA) with six antibiotics against 12 multi-resistant Pseudomonas aeruginosa isolates. Synergic activity was detected with AA chloramphenicol, kanamycin, streptomycin and tetracycline. Indifference was observed to any antibiotics and antagonism only for

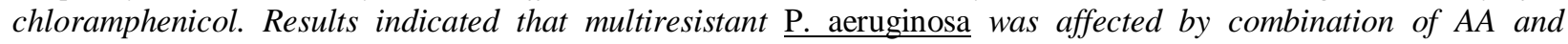
antibiotics. Future research on ascorbic acid-antimicrobial interactions may find new methods to control strains of multiresistant $\underline{P \text {. aeruginosa. }}$.
\end{abstract}

Key words: Ascorbic acid, antibiotic, synergy, Pseudomonas aeruginosa

\section{INTRODUCTION}

Pseudomonas aeruginosa is a versatile pathogen characterized by intrinsic multiple resistance to a variety of antimicrobials and is one of the top three causes of opportunistic human infections and a major causative agent of hospital infections in burns patients (Stover et al., 2000). The emergence of multiresistant $P$. aeruginosa is a potential public health risk and may compromise effective antibiotic therapy with commercially available antibiotics. There is considerable concern about the global increase in antibiotic-resistant bacteria leading to treatment failure (Hancock and Speert, 2000). Studies conducted in the 1970s reported that megadoses of ascorbic acid in combination with antimicrobials inhibited $P$. aeruginosa growth (Rawal et al., 1974; Rawal, 1978). One decade later, other reports suggested that massive doses of ascorbic acid worked synergistically with appropriate antibiotics when used against acute bacterial diseases, and considerably broadened the activity spectrum of the antibiotics (Cathcart, 1985; Cathcart, 1991).

More recently, high doses of ascorbic acid in combination with antibiotics were shown to inhibit the growth of Helicobacter pylori in vitro as well as in vivo (Zhang et al., 1997; Tabak et al., 2003). Other studies have suggested that ascorbic acid may induce the loss of $\mathrm{R}$ plasmids and affect the levels of antibiotic resistance in Staphylococcus (Amabile-Cuevas et al., 1991; Amabile-Cuevas and Heinemann, 2004) and that $\beta$-lactamase activity in Enterobacter cloacae decreased when the bacterium was grown in the presence of ascorbic acid (Shoeb et al., 1995). However, most of these studies included massive doses of ascorbic acid, up to $35 \mathrm{mg} \mathrm{mL}^{-1}$ and only one or two species of a small number of bacterial strains. Thus, there is the need to find new ways to control

* Author for correspondence 
$P$. aeruginosa. One possible therapeutic strategy could be to add ascorbic acid, to appropriate antimicrobial agents, which could work synergistically with or broaden the action spectrum of the antimicrobial against Pseudomonas. In this study, we describe the in vitro assessment of six antibiotics (ampicillin, chloramphenicol, kanamycin, streptomycin, tetracycline and tobramycin) interactions with ascorbic acid $\left(1 \mathrm{mg} \mathrm{mL} \mathrm{mL}^{-1}\right)$ in a series of multiresistant isolates of $P$. aeruginosa.

\section{MATERIALS AND METHODS}

\section{Microorganisms}

A total of 12 isolates of $P$. aeruginosa were used in this study: five clinical isolates obtained from individual patients with burns and nurses and seven isolates from sewage (Magalhães et al., 1997).

\section{Chemicals}

Fresh solutions of chloramphenicol-Cm (ParkeDavis and Co. Ann Arbor, MI, USA) tetracyclineTc (Bristol-Meyers Squibb Co., Syracuse, NY, USA), ampicillin -Ap (Wyeth PA Pharmaceuticals St. Davids, PA, USA), kanamycin-Km (Wyeth Pharmaceuticals St. Davids, PA, USA), streptomycin-Sm (SIGMA, St. Louis, MO, USA) and tobramycin-Tb (FALCON, Brazil) were made using methanol for chloramphenicol and tetracycline and sterile water for the others. Ascorbic acid (Merck and Co., Inc., West Point, PA, USA) solution in distilled sterile water was adjusted to pH 7.0 with $10 \mathrm{~N} \mathrm{NaOH}$ (SIGMA, St. Louis, MO, USA) and added to the media at the required concentration.

Determination of MIC in the presence and absence of ascorbic acid

All cultures were kept in Lignières medium $[0.8 \%$ nutrient broth, (Difco Laboratories, Detroit, MI, USA) $0.5 \%$ gelatin, (SIGMA, St. Louis, MO, USA); 0.7\% agar-agar (Merck and Co., Inc., West Point, PA, USA)] at room temperature prior to MIC determination. The MIC against all isolates was determined by a tube dilution method. Müeller-Hinton broth -MHB (Difco Laboratories, Detroit, MI, USA) was used as the basal medium; the standard inoculum was $3 \times 10^{5} \mathrm{CFU} \mathrm{\textrm {mL } ^ { - 1 }}$ (NCCLS, 2000). Ascorbic acid was added to the basal medium $\left(1 \mathrm{mg} \mathrm{mL} \mathrm{m}^{-1}\right)$ containing increasing concentrations (multiple of two, i.e. 2, 4,..1024 $\mu \mathrm{g}$ $\mathrm{mL}^{-1}$ ) of these antibiotics. Tubes containing an identical amount of basal medium, but free of antibiotic and ascorbic acid, and tubes separately containing the antibiotic or ascorbic acid were included in each assay as a growth control. After $16-24 \mathrm{~h}$ of incubation at $37^{\circ} \mathrm{C}$, the lowest concentration of antibiotic separately or in combination with ascorbic acid, which prevented the development of turbidity, was regarded as the MIC.

\section{Determination of Fractional Inhibitory Concentration (FIC)}

The fractional inhibitory concentration (FIC) was used to interpret the tube dilution method results and calculated as follows (Mackay et al., 2000): FIC of drug $\mathrm{A}=$ MIC drug $\mathrm{A}$ in combination of ascorbic acid / MIC drug A alone. Synergy was defined as an FIC $\leq 0.5$, indifference was defined as an FIC $>0.5$ to 4 , and antagonism was defined as an FIC $>4$.

\section{Determination of AA action on $P$. aeruginosa}

The strains of $P$. aeruginosa $\mathrm{P} 6, \mathrm{P} 18$ and $\mathrm{P} 23$ were grown on $\mathrm{MHB}$ at $37^{\circ} \mathrm{C}$ for $24 \mathrm{~h}$ and diluted to

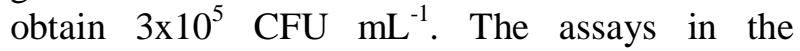
presence of AA were performed as previously described. AA growth interference was determined by spreading $0.1 \mathrm{~mL}$ of bacterial culture after $24 \mathrm{~h}$ of incubation. Enumeration of viable bacteria was performed following $24 \mathrm{~h}$ at $37^{\circ} \mathrm{C}$ on nutrient agar plates.

\section{Statistical analysis}

For all data at least three separate experiments were performed in duplicate. The differences between the zero and $1 \mathrm{mg} \mathrm{mL} L^{-1}$ of $\mathrm{AA}$ for the three isolates of P.aeruginosa were compared using paired-sample T test $(\alpha=0.005)$ according to Zar (1999). 
Table 1 - MIC values $\left(\mu \mathrm{g} \mathrm{mL}{ }^{-1}\right)$ of six drugs in the absence (MIC) and presence (MIC*) of ascorbic acid $1 \mathrm{mg} \mathrm{mL}^{-1}$ and FIC values by drug to 12 isolates of $P$. aeruginosa.

\begin{tabular}{|c|c|c|c|c|c|c|c|c|c|c|c|c|c|c|c|c|c|c|}
\hline \multirow{2}{*}{ Isolates } & \multicolumn{3}{|c|}{ Ampicillin } & \multicolumn{3}{|c|}{ Chloramphenicol } & \multicolumn{3}{|c|}{ Kanamycin } & \multicolumn{3}{|c|}{ Streptomycin } & \multicolumn{3}{|c|}{ Tetracycline } & \multicolumn{3}{|c|}{ Tobramycin } \\
\hline & MIC & MIC* & FIC & MIC & MIC* & FIC & MIC & MIC* & FIC & MIC & MIC* & FIC & MIC & MIC* & FIC & MIC & MIC** & FIC \\
\hline P1 & 1024 & 1024 & $1.0 \mathrm{I}$ & 512 & 512 & $1.0 \mathrm{I}$ & 256 & 256 & $1.0 \mathrm{I}$ & 1024 & 1024 & $1.0 \mathrm{I}$ & 16 & 16 & $1.0 \mathrm{I}$ & 1.0 & 1.0 & $1.0 \mathrm{I}$ \\
\hline P3 & 1024 & 1024 & $1.0 \mathrm{I}$ & 256 & 1024 & $4.0 \mathrm{I}$ & 16 & 16 & $1.0 \mathrm{I}$ & 64 & 64 & $1.0 \mathrm{I}$ & 1024 & 256 & $0.25 \mathrm{~S}$ & 1.0 & 1.0 & $1.0 \mathrm{I}$ \\
\hline P6 & 1024 & 1024 & $1.0 \mathrm{I}$ & 128 & 64 & $0.5 \mathrm{~S}$ & 128 & 32 & $0.25 \mathrm{~S}$ & 64 & 8 & $0.125 \mathrm{~S}$ & 16 & 16 & $1.0 \mathrm{I}$ & 1.0 & 1.0 & $1.0 \mathrm{I}$ \\
\hline P11 & 1024 & 1024 & $1.0 \mathrm{I}$ & 1024 & 1024 & $1.0 \mathrm{I}$ & 64 & 64 & $1.0 \mathrm{I}$ & 4 & 4 & $1.0 \mathrm{I}$ & 1024 & 256 & $0.25 \mathrm{~S}$ & 1.0 & 1.0 & $1.0 \mathrm{I}$ \\
\hline $\mathrm{P} 12$ & 2 & 2 & $1.0 \mathrm{I}$ & 256 & 128 & $0.5 \mathrm{~S}$ & 128 & 2 & $0.01 \mathrm{~S}$ & 4 & 2 & $0.5 \mathrm{~S}$ & 8 & 2 & $0.25 \mathrm{~S}$ & 0.25 & 0.5 & $2.0 \mathrm{I}$ \\
\hline P15 & 1024 & 1024 & $1.0 \mathrm{I}$ & 512 & 1024 & $2.0 \mathrm{I}$ & 1024 & 64 & $0.06 \mathrm{~S}$ & 32 & 16 & $0.5 \mathrm{~S}$ & 16 & 32 & $2.0 \mathrm{I}$ & 0.5 & 1.0 & $2.0 \mathrm{I}$ \\
\hline P16 & 1024 & 1024 & $1.0 \mathrm{I}$ & 256 & 256 & $1.0 \mathrm{I}$ & 64 & 32 & $0.5 \mathrm{~S}$ & 16 & 8 & $0.5 \mathrm{~S}$ & 32 & 32 & $1.0 \mathrm{I}$ & 0.25 & 0.25 & $1.0 \mathrm{I}$ \\
\hline P18 & 1024 & 1024 & $1.0 \mathrm{I}$ & 512 & 256 & $0.5 \mathrm{~S}$ & 512 & 128 & $0.25 \mathrm{~S}$ & 128 & 32 & $0.25 \mathrm{~S}$ & 128 & 32 & $0.25 \mathrm{~S}$ & 1.0 & 1.0 & $1.0 \mathrm{I}$ \\
\hline P19 & 1024 & 1024 & $1.0 \mathrm{I}$ & 1024 & 512 & $.5 \mathrm{~S}$ & 64 & 32 & $0.5 \mathrm{~S}$ & 64 & 32 & $0.5 \mathrm{~S}$ & 64 & 64 & $1.0 \mathrm{I}$ & 1.0 & 2.0 & $1.0 \mathrm{I}$ \\
\hline P22 & 1024 & 1024 & $1.0 \mathrm{I}$ & 512 & 512 & $1.0 \mathrm{I}$ & 32 & 32 & $1.0 \mathrm{I}$ & 34 & 16 & $0.25 \mathrm{~S}$ & 32 & 8 & $0.25 \mathrm{~S}$ & 1.0 & 1.0 & $1.0 \mathrm{I}$ \\
\hline $\mathrm{P} 23$ & 1024 & 1024 & $1.0 \mathrm{I}$ & 16 & 1024 & $64 \mathrm{~A}$ & 256 & 128 & $0.5 \mathrm{~S}$ & 1024 & 1024 & $1.0 \mathrm{I}$ & 16 & 64 & $4.0 \mathrm{I}$ & 16.0 & 16.0 & $1.0 \mathrm{I}$ \\
\hline P24 & 1024 & 1024 & $1.0 \mathrm{I}$ & 128 & 256 & $2.0 \mathrm{I}$ & 64 & 64 & $1.0 \mathrm{I}$ & 1024 & 1024 & $1.0 \mathrm{I}$ & 32 & 8 & $0.25 \mathrm{~S}$ & 8.0 & 16.0 & $1.0 \mathrm{I}$ \\
\hline
\end{tabular}

Table 2 - Survival of three isolates of $P$. aeruginosa in the presence and absence of ascorbic acid in MH broth after 24 hours at $37^{\circ} \mathrm{C}$.

\begin{tabular}{|c|c|c|c|}
\hline \multirow[t]{2}{*}{ P. aeruginosa isolate } & \multicolumn{2}{|c|}{ Concentration of $\mathrm{AA}\left(\mathrm{mg} \mathrm{mL}^{-1}\right)$} & \multirow[t]{2}{*}{ Significance level } \\
\hline & 0.0 & 1.0 & \\
\hline P6 & $5.9^{\#}$ & 7.9 & $\mathrm{P}<0.005 * * *$ \\
\hline P18 & 9.6 & 8.5 & $\mathrm{P}<0.005 * * *$ \\
\hline $\mathrm{P} 23$ & 8.0 & 4.8 & $\mathrm{P}<0.005 * * *$ \\
\hline
\end{tabular}

\section{RESULTS}

The results of combination studies are shown in Table 1. Synergy was detected in four antimicrobial-ascorbic acid combinations. Ampicillin and tobramycin with ascorbic acid did not show synergy against any of the 12 isolates. Synergic effect was observed for $33.3 \%$ (4 of 12) of the isolates in studies of the interactions of AA$\mathrm{Cm}$, for $50 \%$ (6 of 12) of the isolates in studies of the interactions of AA-Tc and for $58.3 \%$ (7 of 12) of the isolates in studies of the interactions of both AA-Km and AA-Sm. For isolate P12, there was a 64-fold reduction in the MIC of kanamycin upon its use in combination.

When ampicillin or tobramycin and ascorbic acid were given in combination to all the isolates, the interaction observed was indifferent. Antagonism (FIC > 4) was observed only in the interactions of
AA-Cm for $8.33 \%$ of the isolates (1 of 12). Chloramphenicol, kanamycin, streptomycin, and tetracycline showed indifference against five to seven (41.67-58.3\%) isolates (Table 1). In order to determine whether $1 \mathrm{mg} \mathrm{mL} \mathrm{m}^{-1}$ concentration influenced P.aeruginosa growth, three isolates that presented FIC interpretation for indifference; antagonism and synergism (P6, P18 and 23, respectively) were chosen. According to paired $\mathrm{T}$ test $(\mathrm{p}<0.005)$ the results indicated that ascorbic acid did not affect the growth of P.aeruginosa for the isolates tested (Table 2).

\section{DISCUSSION}

In this study, among the six antibiotics tested, ampicillin and tobramycin did not demonstrate synergy or antagonism in combination with 
ascorbic acid $\left(1 \mathrm{mg} \mathrm{mL} \mathrm{m}^{-1}\right)$. However, for $P$. aeruginosa and Enterobacter cloacae, $10 \mathrm{mg} \mathrm{mL}^{-1}$ ascorbic acid was able to inhibit the production of $\beta$-lactamase that resulted in susceptibility to ampicillin (Shoeb et al., 1995). It should be noted that this data was obtained for only one strain of $P$. aeruginosa and using a ten-fold higher concentration of ascorbic acid than our study. Since all ampicillin-resistant $P$. aeruginosa isolates tested in the present study were able to produce this enzyme (Magalhães et al., 1997), the heterogeneity of $\beta$-lactamases or the different amounts produced could explain this alternate response to ascorbic acid exposure, or indicate the presence of different mechanisms of ampicillin resistance (Sanders et al., 1988; Bryan, 1988). As expected, ascorbic acid alone at $1 \mathrm{mg} \mathrm{mL} \mathrm{m}^{-1}$ concentration did not affect bacterial growth (Table 2). Most authors have used ascorbic acid at concentrations higher than this with no change in bacterial growth (Shoeb et al., 1995; AmabileCuevas et al., 1991). Tabak et al. (2003) using only $2.0 \mathrm{mg} \mathrm{mL}^{-1}$ of AA for $P$. aeruginosa ATCC 27853 found, however, similar results as observed here.

The synergistic and/ or antagonistic effect was found in AA combination, with kanamycin, streptomycin, tetracycline and chloramphenicol, but not with ampicillin or tobramycin (Table 1). Chloramphenicol showed synergy and antagonism with ascorbic acid. Interestingly, the antagonism was observed only for the isolate P23, which was susceptible to chloramphenicol, according to the guidelines of the National Committee for Clinical Laboratory Standards breakpoint ( $>$ or $=32 \mu \mathrm{g}$ $\mathrm{mL}^{-1}$ ) (NCCLS, 2000).

The interaction of ascorbic acid with tetracycline was clinically more effective in inhibiting antibiotic-resistant $P$. aeruginosa in comparison with other antibiotics tested. The isolates P22 and P24 showed MICs of tetracycline less than the breakpoint of $16 \mu \mathrm{g} \mathrm{mL}^{-1}$ (NCCLS, 2000) when given in combination with ascorbic acid. The interaction, on the other hand, observed for AA Tc showed a $25 \%$ MIC reduction to tetracycline. An interaction of ascorbic acid with tetracycline has been reported for Staphylococcus aureus (Amabile-Cuevas et al., 1991), with ascorbic acid reducing the tetracycline MIC to $50 \%$ and inducing the death of $89 \%$ of an original population exposed to a subinhibitory concentration of the antibiotic. It should be pointed out that the required dosage of an antibiotic used in combination might be less than when used alone, which may further reduce the occurrence of side effects caused by these antimicrobials. The loss of plasmids did not appear to correlate with the effect of the combination of ascorbic acid and antibiotics in this study.

Ascorbic acid did not eliminate the plasmids from any cell of the isolates studied (unpublished data). It is important to remember that ascorbic acid is essential in human tissues and its current recommended dietary allowance (RDA) for adult nonsmoking men and women is $120 \mathrm{mg} /$ day (Carr and Frei, 1999). Results from heart and fertility studies recommend daily doses of ascorbic acid (100 or $500 \mathrm{mg} /$ day) to reduced heart attack risk and increase pregnancy rates. (Osganian et al., 2003; Frei, 2003; Crha et al., 2003). Ascorbic acid is also widely used as a food additive and preservative (Lee et al., 2003), as well as an important antioxidant applied in pharmaceutical and cosmetic industries (Tabak et al., 2003). The increasing consumption of AA is of special interest since increased ascorbic acid levels in blood may possibly compromise effectiveness of antibiotic therapy with chloramphenicol, for example, but may be helpful in the treatment with other antibiotics, such as tetracycline. Ascorbic acid could not only interfere on systemic antibiotics as well as on topic ones, such as those used to treat eye infections, since the levels of ascorbic acid are also increased on human tears under supplementation with vitamin $\mathrm{C}-1 \mathrm{~g} /$ day (Choy et al., 2003).

The effect of antibiotics such as ampicillin, chloramphenicol, cefotaxime, gentamycin, benzyl and procaine penicillin combination (seclopen), co-trimoxazole, and streptomycin in the ascorbic acid concentration has been observed in human plasma (Alabi et al., 1994). As well as the administration ampicillim and cloxacillin with ascorbic acid $\left(25 \mathrm{mg} \mathrm{kg}^{-1}\right)$ is more effective against bovine mastitis caused by Staphylococcus aureus, than only antibiotic combinations (Naresh et al., 2002). These data corroborate that the phenomenon herein reported could occur in vivo. Moreover, the present model used to test the in vitro efficacy of antibiotics against $P$. aeruginosa could help predict the efficacy of the antibiotics in vivo (Mattie, 2000). However, there is difficulty of concluding which antimicrobial-organism combinations will show synergy and may not be a correlation between in vitro synergy and clinical 
efficacy.

The enhancement of antibiotic activity or the reversal of antibiotic resistance by nonconventional antibiotics affords the classification of these compounds as modifiers of antibiotic activity (Gunics et al., 2000; Chakrabarty et al., 1998; Kristiansen and Amaral, 1997; Rajyaguru and Muszynski, 1997). Then, our data suggests that ascorbic acid could be an antibiotic modifier.

In conclusion, this study showed that most combinations studied were synergic or indifferent showing that the application of ascorbic acid combined with these antibiotics could be beneficial in inhibiting antibiotic-resistant $P$. aeruginosa. Further studies in vivo are needed before generalizing the concept of the clinical effectiveness of ascorbic acid in antibiotics such as tetracycline, chloramphenicol, kanamycin and streptomycin for the treatment of P.aeruginosa and also to understand its mechanism of action.

\section{ACKNOWLEDGMENTS}

This work was supported by Conselho Nacional de Desenvolvimento Cientifico e Tecnológico CNPq. The technical assistance of Andréa Reis is gratefully acknowledged.

\section{RESUMO}

Investigou-se in vitro o efeito da combinação do ácido ascórbico (AA) com seis antibióticos frente a 12 isolados multirresistentes de Pseudomonas aeruginosa. As concentrações inibitórias mínimas (CIM) foram determinadas pelo método de diluição em caldo. Foi estudado o efeito do AA nas CIM pelo cálculo das concentrações inibitórias fracionais (CIF). Para quase todas as combinações AA-antibiótico foi detectado efeito sinérgico, exceto para ampicilina e tobramicina. Indiferença foi observada na interação com todos os antibióticos, porém antagonismo foi somente observado para cloranfenicol. Os resultados deste estudo indicam que o sinergismo contra $P$. aeruginosa resistentes pode ocorrer entre AA e cloranfenicol, canamicina, estreptomicina e tetraciclina, ainda que as linhagens sejam resistentes aos antibióticos individualmente. Além disso, estes resultados encorajam futuros trabalhos in vivo a respeito da interação AA-antimicrobianos na incessante busca de novas alternativas para o controle de linhagens multirresistentes de P.aeruginosa.

\section{REFERENCES}

Alabi, Z. O.; Thomas, K. D.; Ogunbona O. and Elegbe, I. A. (1994), The effect of antibacterial agents on plasma vitamin C levels. Afr. J. Med. Med. Sci., 23, 143-146.

Amabile-Cuevas, C. F.; Pina-Zentella R. and WahLaborde, M. E. (1991), Decreased resistance to antibiotics and plasmid loss in plasmid-carrying strains of Staphylococcus aureus treated with ascorbic acid. Mutat. Res., 264, 119-125.

Amabile-Cuevas, C. F. and Heinemann J. A. (2004), Shooting the messenger of antibiotic resistance: plasmid elimination as a potential counterevolutionary tactic. Drug Discov. Today, 9, 465-467.

Bryan, L. E. (1988), General mechanisms of resistance to antibiotics. J. Antimicrob. Chemother, 22, 1-15.

Carr, A. C. and Frei, B. (1999), Toward a new recommended dietary allowance for vitamin $\mathrm{C}$ based on antioxidant and health effects in humans. Am. J. Clin. Nutr., 69, 1086-1107.

Cathcart, R. F. (1985), Vitamin C: The nontoxic, nonrate-limited, antioxidant free radical scavenger. Med. Hypoth., 18, :61-77.

Cathcart, R. F. (1991), A unique function for ascorbate. Med. Hypoth., 35, 32-37.

Chakrabarty A. N.; Dastidar, S. G.; Annadurai, S.; Thakurta, A. G. and Ghosh, K. (1998), Crossresistance among non antibiotics with respect to themselves and antibiotics. In: Chakrabarty, A. N.; Molnár, J.; Dastidar, S. G. and Motohashi, N. (Eds.). Non Antibiotics. pp. 201-208.

Choy, C. K. M.; Benzie, I. F. F. and Cho, P. (2003), Antioxidants in tears and plasma: Inter-relationships and effect of vitamin $\mathrm{C}$ supplementation. Curr eye Res., 27, 55-60.

Crha, I.; Hruba, D.; Ventruba, P.; Fiala, J.; Totusek, J. and Visnova, H. (2003), Ascorbic acid and infertility treatment. Cent. Eur. J. Public. Health., 11, 63-67.

Frei, B. (2003), To C or not to C, that is the question! J. Am. Coll. Cardiol., 42, 253-255.

Gunics, G. N.; Motohashi, L.; Amaral, S. Farkas and Molnar, J. (2000), Interaction between antibiotics and non-conventional antibiotics on different bacteria. Int. J. Antimicrob. Agents, 14, 239-242.

Hancock, R. E. and Speert, D. P. (2000), Antibiotic resistance in Pseudomonas aeruginosa: mechanisms and impact on treatment. Drug. Resist. Updat., 3, 247-255. 
Kristiansen, J. E. and Amaral, L. (1997), The potentional management of resistant infection with non-antibiotics. J. Antimicrob. Chemother., 40, 319-327.

Lee, J. B.; Ahn, J. and Kwak, H. S. (2003), Microencapsulated ascorbic acid for milk fortification. Arch. Pharm. Res., 26, 575-80.

Mackay, M. L.; Milne, K. and Gould, I. M. (2000), Comparison of methods for assessing synergic antibiotic interactions. Int. J. Antimicrob. Agents., 15, 125-129.

Magalhães, P. P.; Reis, A.; Ferreira, M. D. and ChartoneSouza, E. (1997), Resistência a 13 antimicrobianos e ao mercúrio em 25 amostras de Pseudomonas aeruginosa. Rev. Bras. Med., 34,130-136.

Mattie, H. (2000), Antibiotic efficacy in vivo predicted by in vitro activity bacteria. Int. J. Antimicrob. Agents, 14, 91-98.

Naresh, R.; Dwivegi, S. K.; Swarup, D. and Patra, R. C. (2002), Evaluation of ascorbic acid treatment in clinical and subclinical mastitis of indian dairy cows. Asian-Aust. J. Animal Sci., 15, 905-911.

NCCLS - National Committee for Clinical Laboratory Standards (2000), Approved standard M7-A5. Methods for dilution antimicrobial susceptibility tests for bacteria that grow aerobically. 5. ed. NCCLS, Wayne, Pa.

Osganian, S. K.; Stampfer, M. J.; Rimm, E.; Spiegelman, D.; Hu, F. B.; Manson, J. E. and Willett, W. C. (2003), Vitamin C and Risk of Coronary Heart Disease in Women J. Am. Coll. Cardiol., 42, 246-252.

Rajyaguru J. M. and Muszynski M. J. (1997), Enhancement of Burkholderia cepacia antimicrobial susceptibility by cation compounds. J. Antimicrob. Chemother., 40, 345-351.

Rawal, B. D. (1978), Bacterial action of ascorbic acid on Pseudomonas aeruginosa alteration of cell surface as a possible mechanism. Chemotherapy, 24, 166-171.

Rawal, B. D.; McKay, G. and Blackhall M. I. (1974), Inhibition of Pseudomonas aeruginosa by ascorbic acid acting singly and in combination with antimicrobials: in-vitro and in-vivo studies. Med. J. Aust., 1, 169-174.

Sanders, C. C.; Gates, M. L.; and Sanders Jr., W. E. (1988), Heterogeneity of class I beta-lactamase expression in clinical isolates of Pseudomonas aeruginosa. Antimicrob. Agents Chemother., 32, 1893-1895.

Shoeb, H. A.; Al-Shora, H. I. and Abdel-Salam, T. (1995), Ascorbate as an inductor inhibitor of Blactamase in a strain of Enterobacter cloacae. Lett. Appl. Microbiol., 21, 398-401.
Stover, C. K.; Pham, X. Q.; Erwin, A. L.; Mizoguchi, S. D.; Warrener, P.; Hickey, M. J.; Brinkman, F. S.; Hufnagle, W. O.; Kowalik, D. J.; Lagrou, M.; Garber, R. L.; Goltry, L.; Tolentino, E.; Westbrock-Wadman, S.; Yuan, Y.; Brody, L. L.; Coulter, S. N.; Folger, K. R.; Kas, A.; Larbig, K.; Lim, R.; Smith, K.; Spencer, D.; Wong, G. K.; Wu, Z.; Paulsen, I. T.; Reizer, J.; Saier, M. H.; Hancock, R. E.; Lory, S. and Olson, M. V. (2000), Complete genome sequence of Pseudomonas aeruginosa PAO1, an opportunistic pathogen. Nature, 40, 959-964.

Tabak, M.; Armon, R.; Rosenblat, G.; Stermer, E. and Neeman, I. (2003), Diverse effects of ascorbic acid and palmitoyl ascorbate on Helicobacter pylori survival and growth. FEMS Microbiol Lett., 224, 247-253.

Zar, J. H. (1999), Biostatistical analysis. New Jersey : Prentice-Hall. 718 pp.

Zhang, H. M.; Wakisaka, N. O.; Maeda and Yamamoto, T. (1997), Vitamin C inhibits the growth of a bacterial risk factor for gastric carcinoma: Helicobacter pylori. Cancer, 80, 1897-1903.

Received: February 05, 2004; Revised: August 20, 2004; Accepted: March 03, 2005. 